\title{
Kajian Multikultural dalam Bingkai Alkitabiah sebagai Kontribusi Membangun Komunikasi Antarumat Beragama
}

\author{
Yonatan Alex Arifianto \\ Sekolah Tinggi Teologi Sangkakala, Salatiga \\ arifianto.alex@sttsangkakala.ac.id
}

\begin{abstract}
A nation that stood through the struggle of its people, sacrificed a lot of body and soul for the unity and independence of the nation. Must continue to struggle to dispel the nation's own children with various forms of intolerance and discrimination that are spread to each other in a multicultural society. This article aims to examine multiculturalism from a biblical point of view, in which this basis is used as a contribution in building inter-religious communication. Using descriptive qualitative research methods with a literature study approach, it can be concluded that multicultural studies in a biblical frame as a contribution to building communication between religious communities are a priority for believers to remain in the value of mutual respect and appreciation as revealed by the Bible. So believers believe in multicultural values as part of the nation and the attitude of the nation's children in respecting continues to be maintained. This is based on an understanding of multiculturalism in biblical concepts. Which makes believers have an important role in communicating diversity. So that the creation of a pluralistic society in peace and tranquility.
\end{abstract}

Keywords: biblical; communication; multicultural; religious people; tolerance

Abstrak: Bangsa yang berdiri melalui perjuangan rakyatnya, banyak mengorbankan jiwa raga demi persatuan dan kemerdekaan bangsa. Harus terus berjuang menghalau anak bangsa sendiri dengan berbagai bentuk sikap intoleransi maupun deskriminasi yang ditebar kepada sesamanya dalam masyarakat multikultural. Artikel ini bertujuan mengkaji multikultural dari sudut pandang Alkitabiah yang mana dasar tersebut dijadikan kontribusi dalam membangun komunikasi antar umat beragama. Menggunakan metode penelitian kualitatif deskritif dengan pendekatan studi literatur maka dapat disimpulkan bahwa kajian multikultural dalam bingkai alkitabiah sebagai kontribusi membangun komunikasi antar umat beragama, menjadi prioritas bagi orang percaya untuk tetap berada dalam nilai saling menghormati dan menghargai seperti yang diungkapkan oleh Alkitab. Maka orang percaya meyakini nilai multikultural sebagai bagian dari bangsa dan sikap anak bangsa dalam menghargai terus dipertahankan. Hal itu didasari dari pemahaman akan multikultural dalam konsep Alkitabiah. Yang mana hal tersebut menjadikan orang percaya memiliki peran penting dalam mengkomunikasikan keberagaman. Sehingga terciptanya masyarakat yang majemuk dalam kedamaian dan ketenangan.

Kata kunci: alkitabiah; komunikasi; multikultural; toleransi; umat beragama

\section{Pendahuluan}

Keberadaan Bangsa Indonesia yang diperjuangkan para pejuang dan para bapak bangsa adalah negara yang menawan dan terkenal ramah. Dan Indonesia merupakan negara yang indah dan sangat beragam kebudayaan dan kepercayaannya. Negara Kesatuan Republik Indonesia dalam data yang dihimpun memiliki Jumlah penduduknya 220 juta jiwa, hal itu 
membuat bangsa ini menempati urutan jumlah penduduk terbesar keempat dunia. Indonesia dikenal sebagai Negara kepulauan terbesar dengan 18.160 pulau, yang di dalamnya terdapat lebih kurang 366 etnis dan 350 bahasa suku yang berbeda.4 Selain itu, Bangsa ini juga dikenal sebagai bangsa maritim di mana sebagian besar wilayah geografisnya (5,8 juta kilometer persegi) adalah lautan. ${ }^{1}$ Demikian juga dalam hidup bermasyarakat gotong royong dan tepo sliro menjadi semboyan negara yang terkenal ramah ini. Terlebih bangsa Indonesia merupakan bangsa multikultural dengan tingkat pluralisme yang tinggi. Hal itu disebabkan dalam bermasyarakat penduduk negara Indonesia memiliki berbagai latar belakang yang berbeda satu dengan yang lainnya. Adanya keberagaman atau perbedaan itu mempengaruhi bahasa, budaya, kepercayaan. Secara sosiologis, masyarakat Indonesia adalah masyarakat religius dan mudah menerima kebudayaan yang membawa nilai-nilai spiritual. ${ }^{2}$ Namun hal itu berdampak dua sisi yang pertama dapat menjadi potensi kemajuan bangsa sekaligus kemundurannya, namun bergantung pada kualitas pengelolaan heterogenitas tersebut. Yang patut disayangkan hingga saat ini terbukti konflik horizontal yang dilatarbelakangi suku, agama, dan ras antargolongan (SARA) masih sering terjadi dalam masyarakat sosial. ${ }^{3}$

Namun dalam hidup bermasyarakat yang terdiri dari berbagai kebudayaan dan kepercayaan ini juga memiliki spirit kebangsaan yang sama, yang bertujuan membawa nilai keberagaman yang kerap menjadi sumber persoalan dalam kehidupan masyarakat Indonesia. Fakta dilapangan adanya ujaran kebencian baik mengatasnamakan agama, suku dan kepercayaan. Tetapi adanya aksi dari berbagai sikap intoleransi, bahkan persekusi menjadi perkerjaan rumah yang mendesak untuk diselesaikan dalam perjalanan bangsa ini. ${ }^{4}$ Sebab persoalan intoleransi yang menyangkut kerukunan anak bangsa dan umat beragama adalah masalah yang selalu dekat dan kerap terjadi serta menjadi topik yang khas didalam kehidupan masyarakat berbangsa dan negara. Terlebih adanya paham dan aktualisasi dan fundamental dari kelompok intoleran selama ini menodai kerukunan terjadi berakibat fatal. ${ }^{5}$ Sehingga mengakibatkan hubungan antar umat beragama dari sejak dahulu kala selalu mengalami fluktuatif yang tidak stabil, hal itu disebabkan adanya masalah-masalah sosial yang berhubungan kepercayaan dan konsep ajaran yang di aktualisasikan tanpa melihat sisi kehidupan sosial yang memiliki harkat dan martabat yang sama.

Sikap tersebut dapat mengklaim ajaran agamanya paling benar dan memunculkan sikap antipati, bahkan satu sama lain saling menghina dan mere-mehkan baik ajaran maupun ritual ibadah agama lain bahkan menghina pemimpin agama. ${ }^{6}$ Dalam masyarakat multikultural, isu mayoritas dan minoritas, dan pertikaian antar suku, agama harus diselesaikan secara cepat

\footnotetext{
${ }^{1}$ Christia Spears Brown, Michelle Tam, and Frances Aboud, "Ethnic Prejudice in Young Children in Indonesia: Intervention Attempts Using Multicultural Friendship Stories," International Journal of Early Childhood 50, no. 1 (2018): 67-84.

${ }^{2}$ Fransiskus Irwan Widjaja, "Pluralitas Dan Tantangan Misi: Kerangka Konseptual Untuk Pendidikan Agama Kristen Dalam Masyarakat Majemuk," Regula Fidei 4, no. 1 (2019), https://doi.org/10.33541/jrfvol1 iss1pp115.

${ }^{3}$ Dera Nugraha, "Urgensi Pendidikan Multikultural Di Indonesia," Jurnal Pendidikan PKN (Pancasila Dan Kewarganegaraan) 1, no. 2 (2020): 140-49, https://doi.org/10.26418/jppkn.v1i2.40809.

${ }^{4}$ Rikardo Dayanto Butar-Butar et al., "Pengajaran Tuhan Yesus Mengenai Toleransi Dan Implementasinya Ditengah Masyarakat Majemuk," REAL DIDACHE: Jurnal Teologi Dan Pendidikan Agama Kristen 4, no. 1 (2019): 88-101.

${ }^{5}$ Yonatan Alex Arifianto, "Menumbuhkan Sikap Kerukunan Dalam Persepektif Iman Kristen Sebagai Upaya Deradikalisasi," Khazanah Theologia 3, no. 2 (2021): 93-104.

${ }^{6}$ Ujang Saefullah, "Dinamika Komunikasi Dalam Mewujudkan Kerukunan Hidup Antarumat Beragama," Jurnal Ilmu Dakwah 5, no. 1 (2011): 411-44, http://journal.uinsgd.ac.id/index.php/jid/article/view/373.
} 
sebab dapat memicu munculnya isu-isu lain. ${ }^{7}$ Karena adanya perselisihan yang beralasan sentimen agama, maupun politik identitas, telah menjadi komponen utama dalam begitu banyak konflik di Indonesia. Ironisnya hal itu terjadi juga diantara kaum terpelajar dan kaum muda yang menjadi pelaku aksi kekerasan sosial. Sehingga dengan kejadian yang begitu marak di berbagai konflik telah melemahkan keberagaman, solidaritas sebagai negara majemuk dan hal itu merupakan parasit yang harus dihentikan. ${ }^{8}$ Walaupun sejatinya agama dan kepercayaan yang diyakini oleh setiap hak manusia mengajarkan tidak ada agama yang mengizinkan kekerasan, pertikaian serta pembunuhan. ${ }^{9}$

Untuk itu konsep dalam kajian multikulturalisme bukan hanya sebuah gagasan yang kosong atau wacana, melainkan sebuah ideologi yang harus diperjuangkan karena dibutuhkan sebagai landasan bagi tegaknya demokrasi, hak azazi manusia dan kesejahteraan hidup masyarakatnya. Multikulturalisme bukan sebuah ideologi yang berdiri sendiri terpisah dari ideologiideologi lannya. Multikulturalisme membutuhkan seperangkat konsep-konsep yang merupakan bangunan konsep-konsep untuk dijadikan acuan guna memahami dan mengembangluaskannya dalam kehidupan bermasyarakat. ${ }^{10}$ Karena adanya kesadaran bahwa masyarakat negeri ini adalah masyarakat yang heterogen, membuat para pendiri bangsa tidak mau menjadikan satu kultur atau agama tertentu sebagai kultur atau agama dominan yang memayungi semuanya. ${ }^{11}$

Berkaitan dengan topik kajian multikultural dalam bingkai Alkitabiah sebagai kontribusi membangun komunikasi antar umat beragama, pernah diteliti oleh Fredrik Y. A. Doeka dengan penelitian yang berjudul merajut ke-Indonesiaan yang multikultural dalam pandangan gereja. Kesimpulan dari penelitian tersebut adalah bahwa kehadiran gereja di banyak tempat di Indonesia tidak disambut sebagai kawan, melainkan lawan. Kesadaran akan sejarah kelam masa lampau mendorong gereja, untuk melakukan otokritik yaitu dengan cara meninggalkan cara hidup lama dan menggantinya dengan cara hidup baru. Yaitu dengan cara berada di garda depan dan bersama-sama saudara-saudari umat beragama lain, merajut kelndonesiaan yang multikultural. ${ }^{12}$ Begitu juga dengan Nana Najmina melakukan penelitian serupa dalam artikel berjudul pendidikan multikultural dalam membentuk karakter bangsa Indonesia dengan kesimpulan bahwa Pendidikan multikulturalisme harus diterapkan dalam proses pemelajaran melalui proses pembiasaan, pembelajaran multikultural dilakukan dengan pembentukan pola pikir, sikap, tindakan, dan pembiasaan sehingga muncul kesadaran nasional keindonesiaan. ${ }^{13}$ Berdasarkan hal tersebut di atas, maka penelitian tentang Kajian multikultural dalam bingkai alkitabiah sebagai kontribusi membangun komunikasi antar umat beragama dapat mendeskripsikan multikultural yang dilihat dari kajian Alkitab dapat memberikan kontribusi dalam membawa

\footnotetext{
${ }^{7}$ Adon Nasrullah, Agama Dan Konflik Sosial Studi Kerukunan Umat Beragama, Radikalisme Dan Konflik Antarumat Beragama (Bandung: CV.Pustaka Setia, 2015), 56.

${ }^{8}$ Rita Evimalinda, Rikardo Dayanto Butar-butar, and Efvi Noyita, "Membangun Semangat Kebangkitan Nasional Melalui Konten Pendidikan Agama Kristen Multikultural," KHARISMATA: Jurnal Teologi Pantekosta 4, no. 1 (2021): 54-68, https://doi.org/10.47167/kharis.v4i1.92.

${ }^{9}$ Yohanes K Susanta, “Hospitalitas Sebagai Upaya Mencegah Kekerasan Dalam Memelihara Kerukunan Dalam Relasi Islam-Kristen Di Indonesia," Societas Dei: Jurnal Agama Dan Masyarakat 2, no. 1 (2015): 281.

${ }^{10}$ Parsudi Suparlan, "Menuju Masyarakat Indonesia Yang Multikultural," Antropologi Indonesia 35, no. 1 (2014): 98-105, https://doi.org/10.7454/ai.v0i69.3448.

${ }^{11}$ Markus Dominggus L. Dawa, "Menjadi Jemaat Multikultural : Suatu Visi Untuk Gereja-Gereja Tionghoa Injili Indonesia Yang Hidup Di Tengah Konflik Etnis Dan Diskriminasi Rasial," Veritas: Jurnal Teologi Dan Pelayanan 7, no. 1 (2006): 127-44, https://doi.org/10.36421/veritas.v7i1.157.

${ }^{12}$ Fredrik Y A Doeka, "Merajut Ke-Indonesia-an Yang Multikultural Dalam Pandangan Gereja," Millah: Jurnal Studi Agama 18, no. 1 (2018): 15-30.

${ }^{13}$ Nana Najmina, "Pendidikan Multikultural Dalam Membentuk Karakter Bangsa Indonesia," JUPIIS: Jurnal Pendidikan Ilmu-Ilmu Sosial 10, no. 1 (2018): 52-56.
} 
anak bangsa ada dalam hubungan yang baik. Sehingga dengan mudah dapat memahami multikulturalisme, serta berfungsinya multikulturalisme dalam kehidupan manusia. ${ }^{14}$

\section{MeTODE}

Metode yang digunakan dalam penelitian ini adalah penelitian kualitatif deskriptif, ${ }^{15}$ dengan pendekatan studi literature yang dapat mendeskripsikan multikultural dalam bingkai alkitabiah sebagai kontribusi membangun komunikasi antar umat beragama. Penulis melakukan analisis terhadap kajian literatur dan menemukan kajian multikultural dan kontribusinya menjadi data bagi dasar membangun bangsa. Penulis juga menggali informasi dari berbagai sumber literatur berupa jurnal teologi, studi agama-agama ataupun buku-buku yang sesuai dengan topik multikultural, sehingga diperoleh gambaran tentang membangun komunikasi antar umat beragama. Penulis juga memaparkan secara deskriptif dan sistematis sesuai kaidah penulisan terhadap kajian temuan tersebut. Selain menggunakan Alkitab sebagai referensi primer, juga dipergunakan buku-buku dan sumber-sumber sekunder lainnya yang relevan dengan topik sesuai prinsip literatur review yang dimaksud oleh Denney. ${ }^{16}$

\section{Pembahasan}

Multikulturalisme merupakan sebuah ideologi dan sebuah alat atau wahana untuk meningkatkan derajat manusia dan kemanusiannya, maka konsep multikultural harus dilihat dalam perspektif fungsinya bagi kehidupan manusia. Sebab nilai dan makna yang terkandung dalam perspektif tersebut, dan karena itu melihat sisi dari multikultural sebagai pedoman bagi kehidupan manusia dalam menjalani kebudayanaan yang beraneka ragam. ${ }^{17}$ Bila bergerak dari pengertian kata multikultural maka ada dua kata yang ada di situ. Pertama adalah multi dan kedua adalah kultural. Kata multi mengandung arti banyak, lebih dari satu. Sedangkan kata kultural menunjuk pertama kepada kultur atau kebudayaan manusia dalam arti sempit seperti adat-istiadat, namun yang hendak dipakai di sini adalah dalam arti yang seluas-luasnya. ${ }^{18} \mathrm{Na}-$ mun adanya problem dan permasalahan yang kompleks itu memerlukan jalan keluar dan tindakan yang nyata. Sebab sejatinya adanya karakter bangsa yang terpuji, kecerdasan masya-rakat yang prima, nasionalisme Indonesia yang kuat, kemampuan hidup dalam masyarakat dan budaya yang multikultural, sangat perlu menjadi fokus pengembangan pribadi setiap warga bangsa menjadi prioritas dalam membangun komunikasi umat beragama. ${ }^{19}$ Jauh sebelum kemerdekaan bangsa Indonesia konsep multikultural ada dalam pesan Tuhan melalui Alkitab sebagai bukti bahwa hidup harus memiliki prinsip mengasihi Tuhan, sesama, dan lingkungan.

\section{Multikultural sebagai bagian Bangsa dan sikap anak bangsa dalam Menghargai}

Indonesia, jika dilihat dari latar belakang etnis, sosial budaya, bahasa, dan agamanya tak terelakkan memiliki perbedaan-perbedaan. Oleh karena itu, kemajemukan bangsa Indonesia merupakan isu strategis, karena integrasi nasional merupakan landasan persatuan dan kesatuan

\footnotetext{
${ }^{14}$ Suparlan, "Menuju Masyarakat Indonesia Yang Multikultural."

${ }^{15}$ Sonny Eli Zaluchu, "Strategi Penelitian Kualitatif Dan Kuantitatif Di Dalam Penelitian Agama," Evangelikal: Jurnal Teologi Injili Dan Pembinaan Warga Jemaat 4, no. 1 (2020): 28-38, https://doi.org/10.46445/ejti.v4i1.167.

${ }^{16}$ Denney Andrew S. and Richard Tewksbury, "'How to Write a Literature Review,'” Journal of Criminal Justice Education 24, no. 2 (2013): 218-234.

${ }^{17}$ Suparlan, "Menuju Masyarakat Indonesia Yang Multikultural."

${ }^{18}$ Dawa, "Menjadi Jemaat Multikultural : Suatu Visi Untuk Gereja-Gereja Tionghoa Injili Indonesia Yang Hidup Di Tengah Konflik Etnis Dan Diskriminasi Rasial."

${ }^{19}$ Najmina, "Pendidikan Multikultural Dalam Membentuk Karakter Bangsa Indonesia."
} 
bangsa, dan merupakan keharusan bagi terciptanya stabilitas nasional. ${ }^{20}$ Oleh karena itu nilai multikultural pada dasarnya adalah sistem pembelajaran yang dirancang untuk menciptakan masyarakat yang terinformasi dan terpelajar, bukan masyarakat umum yang menghindari faktor sosial dan budaya yang ada. ${ }^{21}$ Selaras dengan hal itu Dede Rosyada mengungkapkan bahwa nilai multikultural merupakan proses pembelajaran yang memberi peluang sama pada seluruh anak bangsa tanpa membedakan perlakuan karena perbedaan etnik, budaya dan agama, yang memberikan penghargaan terhadap keragaman, dan yang memberikan hak-hak sama bagi etnik minoritas, dalam upaya memperkuat persatuan dan kesatuan, identitas nasional dan citra bangsa di mata dunia internasional. ${ }^{22}$

Semua itu dilakukan dengan tujuan kerukunan yang masif disetiap lapisan masyarakat seperti yang dinyatakan oleh Mukti Ali yang dikutip Nazmudin mengatakan bahwa dalam konteks kepentingan negara dan bangsa, kerukunan umat beragama merupakan bagian penting dari kerukunan nasional. Kerukunan umat beragama adalah keadaan hubungan sesama umat beragama yang dilandasi toleransi, saling pengertian, saling menghormati, menghargai kesetaraan dalam pengalaman ajaran agamanya dan kerjasama dalam kehidupan bermasyarakat, berbangsa dan bernegara di dalam Negara Kesatuan Republik Indonesia berdasarkan Pancasila dan Undang-undang Dasar Negara Republik Indonesia Tahun 1945. Oleh karena itu, kerukunan hidup antarumat beragama merupakan prakondisi yang harus diciptakan bagi pembangunan di Indonesia. ${ }^{23}$

Sebagai tindakan yang harus dikerjakan untuk saling menghargai dan menghormati maka peran anak bangsa saling memberikan kebebasan bagi setiap manusia dalam merayakan harihari besar umat beragama serta memperkokoh sikap tegang rasa menjadi kebutuhan dan keputusan yang tepat dalam membangun demokratis. ${ }^{24}$ Maka dari itu untuk mewujudkan kerukunan kehidupan antarumat beragama yang sejati, harus tercipta satu konsep hidup bernegara yang mengikat semua anggota kelompok sosial yang berbeda agama guna menghindari "ledakan konflik antarumat beragama yang terjadi tiba-tiba" ${ }^{25}$ sebab nilai dari hidup berdampingan dalam amsyarakat multikultural serta keberagaman adalah kekuatan dan kelebihan yang sangat istimewa. ${ }^{26}$ Maka sebagai bagian dari anak bangsa harus saling menghargai dan menghormati karena hal itu merupakan aspek yang menjadi kunci dalam melaksanakan pendidikan multikultural bagi masyarakat luas yang digaungkan disetiap lini masyarakat supaya tidak adanya kebijakan yang menghambat toleransi, termasuk tidak adanya penghinaan terhadap ras, etnis dan jenis kelamin. Juga, pendidikan tersebut harus menumbuhkan kepekaan terhadap

\footnotetext{
${ }^{20}$ Evimalinda, Butar-butar, and Noyita, "Membangun Semangat Kebangkitan Nasional Melalui Konten Pendidikan Agama Kristen Multikultural."

${ }^{21}$ Mahmudah Rasyid, "Pendidikan Multikultural Di Pesantren," Guru Tua : Jurnal Pendidikan Dan Pembelajaran 3, no. 2 (2020): 53-62, https://doi.org/10.31970/gurutua.v3i2.58.

${ }^{22}$ Dede Rosyada, "Pendidikan Multikultural Di Indonesia Sebuah Pandangan Konsepsional," SOSIO DIDAKTIKA: Social Science Education Journal 1, no. 1 (2014): 1-12, https://doi.org/10.15408/sd.v1i1.1200.

${ }^{23}$ Nazmudin Nazmudin, "Kerukunan Dan Toleransi Antar Umat Beragama Dalam Membangun Keutuhan Negara Kesatuan Republik Indonesia (NKRI)," Journal of Government and Civil Society 1, no. 1 (2017): 23-39.

${ }^{24}$ Suharsono Suharsono, "Pendidikan Multikultural," EDUSIANA: Jurnal Manajemen Dan Pendidikan Islam 4, no. 1 (2017): 13-23, https://doi.org/10.30957/edusiana.v4i1.3.

${ }^{25}$ Nazmudin, "Kerukunan Dan Toleransi Antar Umat Beragama Dalam Membangun Keutuhan Negara Kesatuan Republik Indonesia (NKRI)."

${ }^{26}$ Dawa, "Menjadi Jemaat Multikultural : Suatu Visi Untuk Gereja-Gereja Tionghoa Injili Indonesia Yang Hidup Di Tengah Konflik Etnis Dan Diskriminasi Rasial."
} 
perbedaan budaya, di antaranya mencakup pakaian, musik dan makanan kesukaan. ${ }^{27}$ Bahkan menghargai nilai iman dan kepercayaan tanpa mengusik dan melecehkannya.

\section{Multikultural dalam Konsep Alkitab}

Alkitab juga mendeskripsikan bagaimana peran manusia dalam menghormati keberadaan budaya dalam konteks multikultural menjadi hal yang penting bagi kerukunan. Allah sejatinya adalah Kasih yang sangat mengharapkan keberadaan sesama manusia saling mengasihi dan hidup dalam kerukunan. Sebab multikultural secara etimologis dan substantif merupakan pengakuan adanya kelompok lain yang sejajar tanpa menghiraukan perbedaan budaya, agama, atau bahasa. ${ }^{28} \mathrm{Hal}$ itu dijabarkan dalam kitab Yunus yang memberikan pesan penting tentang kesadaran multikulturalisme yaitu Dia adalah Allah bagi segenap suku bangsa, ketika Allah memanggiil Yunus untuk pergi ke Niniwe yang berdosa supaya dikabarkan berita pertobatan sehingga mereka tidak menjadi binasa karena kejahatannya. ${ }^{29}$ Karena sejatinya Allah memandang semua suku dan agama memiliki kesempatan yang sama untuk diselamatkan. Dan setiap orang dari bangsa manapun harus hidup berdampingan dan menjadi berkat bagi sesamanya tanpa ada sentimen suku, bangsa, bahasa dan agama. ${ }^{30}$

Multikultural sebagai bagian dari cara pandang Allah terhadap manusia yang beragam budaya. Karena manusia sudah jatuh dalam dosa, Tuhan ingin supaya dalam keberagaman budaya yang dimiliki manusia, manusia dapat dikembali pada hakikat penciptaan manusia yang diciptakan menurut gambar dan rupa Allah, dan ini searah dengan tujuan Allah menciptakan manusia yang dipaparkan dalam Teologi Multikultural satu teologi yang dibangun dari adanya fakta bahwa manusia berada di dalam konteks budaya yang multi, sehingga perlu adanya pendekatan-pendekatan guna melihat peluang supaya dapat melayani serta diterima di semua kalangan. ${ }^{31}$ Sebab Sejatinya aktivitas berteologi dan berbudaya terfokus pada 'subyek' yang sama yaitu 'manusia'. Manusialah yang berteologi dan berbudaya. Karena keduanya dilakukan oleh pribadi yang sama, maka interaksi keduanya tak terhindarkan. ${ }^{32}$

Allah menciptakan manusia menurut gambar dan rupa-Nya yang diperlengkapi dengan kemampuan mengaktualisasi diri dalam hubungannya dengan Tuhan, dirinya sendiri, dan alam sekitarnya untuk keberlangsungan hidupnya. Karena itulah manusia disebut sebagai makhluk yang berbudaya. Namun karena dosa mengakibatkan seluruh aspek kebudayaannyapun dipengaruhi dosa, sehingga tidak lagi tertuju memuliakan Allah. Meski demikian Allah tetap mengasihi manusia, maka la berinkarnasi menjadi manusia dengan melalui pribadi Yesus untuk menyelamatkannya beserta seluruh aspek budayanya. Penyelamatan ini merupakan pemulihan relasi baik dengan Allah, sesamanya dan alam lingkungannya. Untuk itu orang yang sudah diselamatkan oleh karya pengudusan Kristus akan berfungsi merefleksikan karya kristus

\footnotetext{
${ }^{27}$ Suharsono, "Pendidikan Multikultural."

${ }^{28}$ Nugraha, "Urgensi Pendidikan Multikultural Di Indonesia."

${ }^{29}$ Evimalinda, Butar-butar, and Noyita, "Membangun Semangat Kebangkitan Nasional Melalui Konten Pendidikan Agama Kristen Multikultural."

${ }^{30}$ Evimalinda, Butar-butar, and Noyita.

${ }^{31}$ Desiana M Nainggolan, "Model Misi Ramah Kemanusiaan Bagi Marginal People Berdasarkan Teologi Multikultural Di Lembaga Misi 'Inti Terang Semesta' Batam Kepulauan Riau," Missio Ecclesiae 10, no. 2 (2021): 10325.

${ }^{32}$ Gunaryo Sudarmanto, "Meretas Rancang Bangun Teologi Multikultural," Voice of Wesley: Jurnal Ilmiah Musik Dan Agama 1, no. 1 (2019): 121-46, https://doi.org/10.36972/jvow.v1i1.6.
} 
di seluruh sektor kebudayaannya, agar manusia dan budayanya kembali memuliakan Allah Sang Pencipta. ${ }^{33}$

Dasar pokok dan utama dari perspektif Kristen tentang kesadaran multikulturalisme adalah model yang ditetapkan oleh Yesus Kristus. Hal ini tidak dapat dibantah sebab Yesus atau keKristenan hadir, berkarya dan beredar dimulai dari Kristus, oleh Kristus dan bagi Kristus. ${ }^{34}$ Terlebih Yesus sebagai patokan, teladan dalam mengaktualisasi keberagaman dalam kehidupan bermasyrakat. Yesus juga menjadi tokoh central iman Kristen dalam mempraktek hidup pelayanan dan pengajaranNya mewariskan nilai luhur tentang toleransi dan keberagaman budaya atau multikultural. Oleh karena itu sebagai makluk bernama manusia dan sebagai "sesama manusia" wajib hidup harmoni dalam kasih. ${ }^{35}$ Sebab pengajaran Yesus tentang sikap saling mengasihi adalah bukti yang kuat bagi karakteristik iman Kristen yang harus diaktualisasikan, sehingga diharapkan dapat menjadi berkat dan terang bagi sesama manusia, dilandaskan dan diikat dengan kasih, sebagaimana tertulis dalam Kolose 3:14. ${ }^{36}$

Perjanjian Baru juga mencatat salah satu inti utama pengajaran Tuhan Yesus yang berkaitan dengan kemajemukan dalam lini multikultural dan toleransi adalah mengasihi sesama manusia seperti diri sendiri. Yesus dalam pengajaranNya menempatkan manusia sebagai sesama yang harus dipandang dan diperlakukan sebagai objek kasih dimana ukuran perlakuan kepada orang lain tidak mengenal batas agama, suku dan ras tetapi harus didasarkan pada kasih. Perintah Tuhan Yesus untuk mengasihi sesama manusia seperti diri sendiri. ${ }^{37}$ Bahkan pada masa Yesus ada sebuah tradisi dalam menyambut seorang tamu dengan sikap saling menghormati, mengasihi, hidup dalam kasih yang toleran dan penuh berkat. Hidup damai dan rukun menjadi panggilan semua pihak agar membuka diri terhadap perbedaan keyakinan. Untuk itu setiap orang percaya dan sebagai anak bangsa di Indonesia ini harus berupaya menumbuhkan sikap toleran, tidak saling menghakimi, melepaskan diri dari klaim absolut yang sering membutakan diri terhadap pluralitas di tengah-tengah masyarakat (Mat. 26:7). ${ }^{38}$

Kemajemukan dalam multikultural yang Allah ciptakan menjelaskan Allah akan tetap setia menjadi Allah yang baik bagi semua orang dan Allah mengasihi manusia (Mzm. 145:9), karena bagi Allah bahwa manusia diciptakan sebagai makhluk sosial yang hidup bersama-sama dengan sesamanya. Tanpa kehadiran sesama manusia sebagai makluk sosial maka seorang manusia tidak lengkap, dan tidak mempunyai arti dalam kebersamaan. Terlebih sejatinya manusia tidak bisa hidup tanpa kehadiran orang lain. Oleh karena itu Allah menciptakan manusia sebagai makluk sosial yang memiliki beragam perbedaan-perbedaan dengan tujuan supaya manusia untuk saling melayani, saling membantu, saling mengisi, saling melengkapi, saling menolong antara sesama manusia. Dengan perbedaan tersebut maka setiap manusia bisa membangun relasi yang baik dengan orang lain yang berbeda etnis, kepercayaan maupun sikap ${ }^{39}$

\footnotetext{
${ }^{33}$ Sudarmanto.

${ }^{34}$ Butar-Butar et al., "Pengajaran Tuhan Yesus Mengenai Toleransi Dan Implementasinya Ditengah Masyarakat Majemuk."

${ }^{35}$ Butar-Butar et al.

${ }^{36}$ Yonatan Alex Arifianto and Joseph Christ Santo, "Tinjauan Trilogi Kerukunan Umat Beragama Berdasarkan Perspektif Iman Kristen," Angelion: Jurnal Teologi Dan Pendidikan Kristen 1, no. 1 (June 2020): 1-14, https://doi.org/10.38189/jan.v1i1.38.

${ }^{37}$ Butar-Butar et al., "Pengajaran Tuhan Yesus Mengenai Toleransi Dan Implementasinya Ditengah Masyarakat Majemuk."

${ }^{38}$ Ginting.

${ }^{39}$ Meri Ulina Br Ginting, "PENDIDIKAN PAK BERBASIS MULTIKULTURAL DI SEKOLAH (Suatu Tinjauan Teologis Dan Praktis Tentang Pendidikan Multikultural Di Sekolah)," Jurnal Sabda Penelitian 1, no. 2 (2021): 1-15, https://ejurnal.sttabdisabda.ac.id/index.php/JSPL/article/view/40.
} 


\section{Peran Orang Percaya dalam Mengkomunikasikan Keberagaman}

Kekristenan hadir menjadi dampak bagi manusia untuk dapat memberikan keteladan disegala lini kehidupan termasuk dalam sikap menghargai dan menghormati sesama dalam bingkai multikultural. Perintah Yesus untuk pergi dan menajdikan bangsa-bangsa menjadi murid-Nya merupakan kebaikan Allah bagi umat manusia yang beragam tersebut. Untuk itu betapa pentingnya pemahaman akan sikap terhadap multikultural bagi orang percaya terkhusus generasi muda, karena pada era disrupsi seperti saat ini salah satu kompetensi yang dibutuhkan dalam dunia pendidikan adalah kemampuan generasi muda untuk memecahkan masalah dari berbagai hal termasuk dari persoalan yang terjadi di ranah multikultural. ${ }^{40}$ Sebab sejatinya orang percaya diharapkan berdampak bagi sekeliling dan mereka juga dituntut untuk menampilkan dirinya sebagai saksi, terang dan garam dunia kepada kepercayaan lain dalam semangat toleransi dan semangat kemajemukan. ${ }^{41}$ Kesadaran berbangsa menjadi alasan yang kuat untuk mempertahankan inti idiologi negara. Dan sikap pengamalan agama secara universal dalam arti menghargai kebergaman dan kepercayaan dalam hidup toleran adalah tanggung jawab anak bangsa dari seluruh lapisan masyarakat, dengan mengaktualisasi bahwa setiap golongan umat beragama menampakkan sikap saling mengerti, menghormati, dan menghargai. ${ }^{42}$

Namun bila orang Kristen membangun kerukunan dengan cara membedakan orang dengan mendiskriminasi, bahkan membuat politik identitas semakin menjadi besar hal itu merupakan kerukunan yang palsu, jahat dan amoral sebab tidak didasari dengan hati yang penuh kasih, kebenaran, keadilan dan kebebasan. Sehingga kerukunan yang diciptakan itu hanya menyembunyikan dan menunda konflik untuk meledak antar umat beragama dalam masyarakat. ${ }^{43}$ untuk itu seperti yang dinyatakan oleh Sairin bahwa: Bangsa Indonesia adalah bangsa yang besar dan memiliki kemajemukan dalam bermasyarakat heterogen dan keberadaan Indonesia juga adalah anugerah agung Allah untuk dirawat, untuk dipelihara, dan untuk dikembangkan tetapi bukan untuk diacak-acak. ${ }^{44}$ Maka orang Kristen harus memiliki sikap dalam mengaktualisasi nilai kerukunan yang mencerminkan Kristus dan menjadi dampak dalam segala hal yang baik bagi sesama dosetiap market place yang telah Tuhan tetapkan orang percaya berada dan melayani Tuhan dan sesama. ${ }^{45}$

Tugas besar orang percaya dalam merawat kemajemukan masyarakat semakin berat melihat berbagai fenomena dan tumbuhnya berbagai sikap intoleransi ditengah masyarakat masa kini. Toleransi yang adalah "nyawa" dan "roh" membangun harmoni dalam masyarakat majemuk seolah sirna oleh pancaran pengajaran radikalisme antar dan inter agama yang lam-

\footnotetext{
${ }^{40}$ Abdul Rohman and Yenni Eria Ningsih, "Pendidikan Multikultural : Penguatan Identitas Nasional Di Era," Seminar Nasional Multidisiplin 2018, no. September (2018): 44-50.

${ }^{41}$ Daeli Dorkas Orieti and Sonny Eli. Zaluchu, "Analisis Fenomenologi Deskriptif Terhadap Panggilan Iman Kristen Untuk Kerukunan Antar Umat Beragama Di Indonesia," JURNAL SUNDERMANN, 2019, https://doi.org/https://doi.org/10.36588/sundermann.vlil.27.

42 Darwis Muhdina, "Kerukunan Umat Beragama Berbasis Kearifan Lokal Di Kota Makassar," Jurnal Diskursus Islam 3, no. 1 (2015),

https://scholar.google.com/citations?view_op=view_citation\&hl=id\&user=YUlszp0AAAAJ\&citation_for_view=YUlszp OAAAAJ:qjMakFHDy7sC.

${ }^{43}$ Weinata Sairin, "Kerukunan Umat Beragama Pilar Utama Kerukunan Berbangsa: Butir-Butir Pemikiran," 2002,180

${ }^{44}$ Weinata Sairin, Visi Gereja Memasuki Milenium Baru (Jakarta: BPK Gunung Mulia, 2002), 125.

${ }^{45}$ Simon Simon and Yonatan Alex Arifianto, "Kerukunan Umat Beragama Dalam Bingkai Iman Kristen Di Era Disrupsi," JURNAL PENGABDIAN MASYARAKAT DAN INOVASI 1, no. 1 (2021): 35-43.
} 
bat laun telah merobek semangat kebersamaan dalam kebhinnekaan. ${ }^{46}$ Seperti yang diungkapakan oleh Robert Schreiter yang dikutip oleh Dawa mengatakan bahwa orang percaya sebagai Jemaat multikultural adalah jemaat yang menerima dan mengakui kehadiran orang lain dengan segala perbedaan yang dibawanya, menghormati perbedaan-perbedaan itu dan menyediakan suatu ruang di mana terjadi interaksi yang sehat di antara perbedaan itu. ${ }^{47}$ Maka Kekristenan sebagai bagian dari Masyarakat Indonesia yang memiliki beragam perbedaan multikultural atau majemuk. Maka esensi dari nilai Kemajemukan sangat penting untuk dihargai sehingga tercipta masyarakat yang hidup dalam damai, hidup untuk saling menghormati, saling memberikan pertolongan serta hidup dalam kerukunan. Maka segala apa yang diaktua-lisasikan tersebut dapat menciptakan dan toleransi di tengah-tengah masyarakat sehingga terciptalah rasa persaudaraan di Negara Republik Indonesia. ${ }^{48}$ Terlebih terciptanya ketentraman dan rasa persaudaraan yang dapat membangun bangsa lebih maju di segala lini kehidupan berbangsa.

\section{KESIMPULAN}

Melihat dari berbagai tindakan anarkis dan intoleransi yang terjadi saat ini maka sikap orang percaya dalam mengaktualisasi hidup berdampingan dengan rukun dalam masyarakat multikultural terus dijaga walaupun kondisi dan sikap manusia lebih mengasihi diri sendiri dan komunitasnya. Dengan demikian dapat disimpulkan bahwa kajian multikultural dalam bingkai Alkitabiah sebagai kontribusi membangun komunikasi antar umat beragama, menjadi prioritas bagi orang percaya untuk tetap berada dalam nilai saling menghormati dan menghargai seperti yang diungkapkan oleh Alkitab. Maka orang percaya meyakini nilai multikultural sebagai bagian dari bangsa dan sikap anak bangsa dalam menghargai terus dipertahankan. Hal itu didasari dari pemahaman akan multikultural dalam konsep Alkitabiah. Yang mana hal tersebut menjadikan orang percaya memiliki peran penting dalam mengkomunikasikan keberagaman. Sehingga terciptanya masyarakat yang majemuk dalam kedamaian dan ketenangan.

\section{REFERENSI}

Arifianto, Yonatan Alex. "Menumbuhkan Sikap Kerukunan Dalam Persepektif Iman Kristen Sebagai Upaya Deradikalisasi." Khazanah Theologia 3, no. 2 (2021): 93-104.

Arifianto, Yonatan Alex, and Joseph Christ Santo. "Tinjauan Trilogi Kerukunan Umat Beragama Berdasarkan Perspektif Iman Kristen." Angelion: Jurnal Teologi Dan Pendidikan Kristen 1, no. 1 (June 2020): 1-14. https://doi.org/10.38189/jan.v1i1.38.

Brown, Christia Spears, Michelle Tam, and Frances Aboud. "Ethnic Prejudice in Young Children in Indonesia: Intervention Attempts Using Multicultural Friendship Stories." International Journal of Early Childhood 50, no. 1 (2018): 67-84.

Butar-Butar, Rikardo Dayanto, Ester Lina Situmorang, Jabes Pasaribu, and Manahan Uji Simanjuntak. "Pengajaran Tuhan Yesus Mengenai Toleransi Dan Implementasinya Ditengah Masyarakat Majemuk." REAL DIDACHE: Jurnal Teologi Dan Pendidikan Agama Kristen 4, no. 1 (2019): 88-101.

Darwis Muhdina. "Kerukunan Umat Beragama Berbasis Kearifan Lokal Di Kota Makassar." Jurnal Diskursus Islam 3, no. 1 (2015).

https://scholar.google.com/citations?view_op=view_citation\&hl=id\&user=YUlszp0AAAAJ \&citation_for_view=YUlszp0AAAAJ:qjMakFHDy7sC.

\footnotetext{
${ }^{46}$ Butar-Butar et al., "Pengajaran Tuhan Yesus Mengenai Toleransi Dan Implementasinya Ditengah Masyarakat Majemuk."

${ }^{47}$ Dawa, "Menjadi Jemaat Multikultural : Suatu Visi Untuk Gereja-Gereja Tionghoa Injili Indonesia Yang Hidup Di Tengah Konflik Etnis Dan Diskriminasi Rasial."

${ }^{48}$ Ginting, "PENDIDIKAN PAK BERBASIS MULTIKULTURAL DI SEKOLAH (Suatu Tinjauan Teologis Dan Praktis Tentang Pendidikan Multikultural Di Sekolah)."
} 
Dawa, Markus Dominggus L. "Menjadi Jemaat Multikultural : Suatu Visi Untuk Gereja-Gereja Tionghoa Injili Indonesia Yang Hidup Di Tengah Konflik Etnis Dan Diskriminasi Rasial." Veritas: Jurnal Teologi Dan Pelayanan 7, no. 1 (2006): 127-44. https://doi.org/10.36421/veritas.v7i1.157.

Doeka, Fredrik Y A. "Merajut Ke-Indonesia-an Yang Multikultural Dalam Pandangan Gereja." Millah: Jurnal Studi Agama 18, no. 1 (2018): 15-30.

Evimalinda, Rita, Rikardo Dayanto Butar-butar, and Efvi Noyita. "Membangun Semangat Kebangkitan Nasional Melalui Konten Pendidikan Agama Kristen Multikultural." KHARISMATA: Jurnal Teologi Pantekosta 4, no. 1 (2021): 54-68. https://doi.org/10.47167/kharis.v4i1.92.

Ginting, Meri Ulina Br. "PENDIDIKAN PAK BERBASIS MULTIKULTURAL DI SEKOLAH (Suatu Tinjauan Teologis Dan Praktis Tentang Pendidikan Multikultural Di Sekolah)." Jurnal Sabda Penelitian 1, no. 2 (2021): 1-15. https://ejurnal.sttabdisabda.ac.id/index.php/JSPL/article/view/40.

Nainggolan, Desiana M. "Model Misi Ramah Kemanusiaan Bagi Marginal People Berdasarkan Teologi Multikultural Di Lembaga Misi 'Inti Terang Semesta' Batam Kepulauan Riau." Missio Ecclesiae 10, no. 2 (2021): 103-25.

Najmina, Nana. "Pendidikan Multikultural Dalam Membentuk Karakter Bangsa Indonesia." JUPIIS: Jurnal Pendidikan IImu-IImu Sosial 10, no. 1 (2018): 52-56.

Nasrullah, Adon. Agama Dan Konflik Sosial Studi Kerukunan Umat Beragama, Radikalisme Dan Konflik Antarumat Beragama. Bandung: CV.Pustaka Setia, 2015.

Nazmudin, Nazmudin. "Kerukunan Dan Toleransi Antar Umat Beragama Dalam Membangun Keutuhan Negara Kesatuan Republik Indonesia (NKRI)." Journal of Government and Civil Society 1, no. 1 (2017): 23-39.

Nugraha, Dera. "Urgensi Pendidikan Multikultural Di Indonesia." Jurnal Pendidikan PKN (Pancasila Dan Kewarganegaraan) 1, no. 2 (2020): 140-49. https://doi.org/10.26418/jppkn.v1i2.40809.

Orieti, Daeli Dorkas, and Sonny Eli. Zaluchu. "Analisis Fenomenologi Deskriptif Terhadap Panggilan Iman Kristen Untuk Kerukunan Antar Umat Beragama Di Indonesia." JURNAL SUNDERMANN, 2019. https://doi.org/https://doi.org/10.36588/sundermann.vlil.27.

Rasyid, Mahmudah. "Pendidikan Multikultural Di Pesantren." Guru Tua : Jurnal Pendidikan Dan Pembelajaran 3, no. 2 (2020): 53-62. https://doi.org/10.31970/gurutua.v3i2.58.

Rohman, Abdul, and Yenni Eria Ningsih. "Pendidikan Multikultural : Penguatan Identitas Nasional Di Era." Seminar Nasional Multidisiplin 2018, no. September (2018): 44-50.

Rosyada, Dede. "Pendidikan Multikultural Di Indonesia Sebuah Pandangan Konsepsional." SOSIO DIDAKTIKA: Social Science Education Journal 1, no. 1 (2014): 1-12. https://doi.org/10.15408/sd.v1i1.1200.

S., Denney Andrew, and Richard Tewksbury. "How to Write a Literature Review,.'" Journal of Criminal Justice Education 24, no. 2 (2013): 218-234.

Saefullah, Ujang. "Dinamika Komunikasi Dalam Mewujudkan Kerukunan Hidup Antarumat Beragama." Jurnal Ilmu Dakwah 5, no. 1 (2011): 411-44. http://journal.uinsgd.ac.id/index.php/jid/article/view/373.

Sairin, Weinata. "Kerukunan Umat Beragama Pilar Utama Kerukunan Berbangsa: Butir-Butir Pemikiran," 2002.

_. Visi Gereja Memasuki Milenium Baru. Jakarta: BPK Gunung Mulia, 2002.

Simon, Simon, and Yonatan Alex Arifianto. "Kerukunan Umat Beragama Dalam Bingkai Iman Kristen Di Era Disrupsi." JURNAL PENGABDIAN MASYARAKAT DAN INOVASI 1, no. 1 (2021): 35-43.

Sudarmanto, Gunaryo. "Meretas Rancang Bangun Teologi Multikultural." Voice of Wesley: Jurnal Ilmiah Musik Dan Agama 1, no. 1 (2019): 121-46. https://doi.org/10.36972/jvow.v1i1.6. 
Suharsono, Suharsono. "Pendidikan Multikultural." EDUSIANA: Jurnal Manajemen Dan Pendidikan Islam 4, no. 1 (2017): 13-23. https://doi.org/10.30957/edusiana.v4i1.3.

Suparlan, Parsudi. "Menuju Masyarakat Indonesia Yang Multikultural." Antropologi Indonesia 35, no. 1 (2014): 98-105. https://doi.org/10.7454/ai.v0i69.3448.

Susanta, Yohanes K. "Hospitalitas Sebagai Upaya Mencegah Kekerasan Dalam Memelihara Kerukunan Dalam Relasi Islam-Kristen Di Indonesia." Societas Dei: Jurnal Agama Dan Masyarakat 2, no. 1 (2015): 281.

Widjaja, Fransiskus Irwan. "Pluralitas Dan Tantangan Misi: Kerangka Konseptual Untuk Pendidikan Agama Kristen Dalam Masyarakat Majemuk." Regula Fidei 4, no. 1 (2019). https://doi.org/10.33541/jrfvol1 iss1pp115.

Zaluchu, Sonny Eli. "Strategi Penelitian Kualitatif Dan Kuantitatif Di Dalam Penelitian Agama." Evangelikal: Jurnal Teologi Injili Dan Pembinaan Warga Jemaat 4, no. 1 (2020): 28-38. https://doi.org/10.46445/ejti.v4i1.167. 